\title{
Being Moved to the Outer Edge - Experiences of Working with Newly Arrived Students in a Newly Diverse School
}

\author{
Anna Ehrlin and Ulrika Jepson Wigg \\ Mälardalen University \\ Eskilstuna, Sweden
}

\begin{abstract}
The purpose of the study is to examine and analyse teachers' and their principal's experiences of receiving a group of newly arrived students at a newly diverse school, in order to highlight how this impacts professional practice and what is important to take into account when receiving and teaching newly arrived students. The study is based on experiences from a research-and development program, with additional data gathered from semi-structured interviews with eight teachers and a principal at a rural school. The theoretical point of departure is Wenger's (1998) theory on communities of practice and legitimate peripheral participation. The results show that the teachers were not prepared for the sudden change in the practice, and that the teachers' were frustrated with being limited as professionals. The change wasn't merely a change in student demographics but a significant change in the community or practice. Analytically, we understand this as being moved to the outer edge, from being central participants in the practice. The result shows that such a change requires focus on preparations and structures for reflection and support, so that teachers are able to again become competent actors and develop their teaching, in relation to newly arrived students.
\end{abstract}

Keywords: Newly arrived students; communities of practice; legitimate peripheral participation; diverse schools; compulsory school.

\section{Introduction and background}

This article focuses on teachers' experiences of working at a school which over the course of a semester went from having a mono-cultural and locally rooted group of students, to receiving a relatively large number of newly arrived students. The school can therefore be described as a newly diverse school. The study is focused on secondary school, since most of the newly arrived students at this particular school were placed there.

Schooling for newly arrived students in Sweden is regulated in the Education Act (SFS 2010:800), and states that all children have the right to attend school. A 
student is regarded newly arrived for four years. In 2016 the law was changed in order to assure equal education for newly arrived students in compulsory school. For instance, the term "newly arrived students" became an official term. In addition, there are national guidelines and advice for school organisers, principals and teachers. Schools can opt to place students in an introductory group for a period of no more than two years (support material provided by the National Agency of Education, 2016). Many schools offer extra support for a period of time, either language support or study support.

Due to demography and housing segregation, most municipalities have one or a few schools, depending on the size of the municipality, which receive the vast majority of newly arrived students. The demand to receive newly arrived students is only placed on the municipality run schools, who are in the closest vicinity to the students' place of residence. Although all students in Sweden have the right to choose another school, studies have shown that students with a migrant background rarely do so (Bunar, 2015), and this includes newly arrived students.

During the autumn of 2015 and the spring of 2016, Sweden saw a sharp rise of the number of refugees that sought asylum. This in turn affected the recipient schools, whose capacity quickly was overburdened. Consequently, many schools who did not previously receive newly arrived students, or received only a few students each year had to make room for these students. Receiving and teaching newly arrived students puts certain pedagogical demands on the teachers and on the organisation as a whole Jepson Wigg (2016) and many schools did not have the experience or competence needed.

Countryside school, which is in focus in this article, was one of the schools that decided to start receiving newly arrived students during this time. The teachers at the school ran into a number of professional problems, and over the course of a research- and development programme that we were involved in as researchers, we came into contact with these problems.

\section{Aim and research questions}

The aim of the study is to examine and analyse teachers' and their principal's experiences of receiving a group of newly arrived students at a school which over the course of a semester went from having a mono-cultural and locally rooted group of students, to receiving a relatively large number of newly arrived students. The research questions are: How does this sudden change impact professional practice? and, What is important to take into account when receiving and teaching newly arrived students?

\section{Research and Policy Reports on Schooling for Newly Arrived Students}

In a report from OECD, the differences in school performance between native students and students with an immigrant background is highlighted. The older the student at the time of arrival in the new country, the larger the gap. A policy brief from the RAND Corporation (2016) points to the same gap. Factors that promote success are among other a holistic perspective on the students' school- 
and life situation, and a wide approach to inclusion (ibid.). The Swedish Research Council emphasises in an overview of current educational research (2019), that there has been an increase in Sweden of students with a background from different schools systems, and with limited schooling, and that this impacts schools and students in ways that are not fully investigated in current research.

Internationally, "newly arrived students" is not an established term, but rather studies regarding these students are found in the field of "immigrant students" or "migrant students". There is some common ground between these terms and the field of "refugee education", although those studies often focus on education for refugees living in encampments in neighbouring countries. In Swedish educational research, there is a growing number of studies regarding newly arrived students, but only some of them are available in English. For the purposes of this article, we have chosen to use the term "newly arrived students" in the presentation of previous research.

Several studies, both in Sweden and internationally, bring up what is often referred to as the deficit model in relation to newly arrived students. The students are understood as lacking knowledge in relation to the school system in the new country, which is reinforced in those cases when students have traumatic experiences (Pastoor, 2015; Nilsson \& Bunar, 2016; Devine \& McGillicuddy, 2016). Studies point to a lack of coordination and structure in the support offered to the students, which means that teachers' work with these students risk being ad hoc. This might lead to teachers lowering their expectations and demands on students (Devine \& McGillicuddy, 2016). Several studies show that methods such as ability grouping and tracking have proven negative for newly arrived students, and may lead to lowered expectations and a deficit model thinking (see for example Bartlett, 2015). A counterweight to this is adopting a holistic approach around newly arrived students, in order to create equal opportunities for learning (Hattam \& Every, 2010; Adelman \& Taylor, 2015; Devine \& McGillicuddy, 2016; Dryden-Peterson, 2017). Other studies raise the need to question diminishing stereotypes and to adopt a wider perspective on newly arrived students' learning and how their experiences and competencies might be incorporated and made use of in education (Hattam \& Every, 2010; Catarci, 2014; Nilsson \& Bunar, 2016; Devine \& McGillicuddy; Dryden Petersen, 2016, 2017; Migliarini, 2017).

A longitudinal study, which focused on the process of a small city becoming more diverse due to policy decisions (Simó \& Telford, 2012), summarizes the effectiveness of different strategies in handling increasing diversity in school. The study took place over 15 years, and states that in order to succeed in creating integration and a school which supports all students, a number of aspects need to be addressed and processed. One aspect is organising reception classes as open spaces, to make sure that the newly arrived students are not sealed off, and so that all students have access to that space. Another is to recognize the crucial role that other students play in the newly arrived students' development of language. A third aspect concerns the need to organize training for teachers, which includes space and time for reflection and analysis of learning possibilities of all students, and developing structures that support that 
work. The authors of the study also stress that decisions that so fundamentally change a community, need to be anchored in practice (Simó \& Telford, 2012).

\section{Theoretical framework}

The theoretical point of departure for this study is Wenger's (1998) theory on communities of practice. In the context of this study, collaboration between teachers at Countryside School and between teachers and the principal, can be understood as communities of practice that are interconnected to a varying extent. The starting point in Wenger's (1998) theory is that, in our everyday lives, we form part of several communities of practice that affect our development, and that within these communities we affect practice to different degrees. Participating in a community of practice changes the individual as well as their position in community. Within a community of practice, an individual's participation can be understood as a shift from being a legitimate peripheral participant or actor on the outer edge of a community to, over time, becoming an increasingly central participant or actor who has increasingly mastered that community of practice. This learning process is based on the interplay between the people in the community of practice (Wenger, 1998).However, sometimes individuals might find themselves in a situation when previous knowledge within the practice isn't relevant or enough to handle the new situation. Our interpretation is that these situations bring us back to a position on the outer edge of the community, and in a sense we are back to being peripheral participants. Wenger stresses that in order to deal with this, community building must ... make sure that participants have access to the resources necessary to learn what they need to learn in order to take actions and make decisions that fully engage their own knowledgeability (Wenger, 2018, p.225).

\section{Method and Empirical Material}

Countryside School is a compulsory school situated in a municipality of about 1300 inhabitants where most of the inhabitants of the village were born in Sweden. The school has students in grades 1 to 9. In2016, approximately 30 newly arrived students came to study at the school. All of them lived in a municipality of 100000 inhabitants, $30 \mathrm{~km}$ away and the municipality arranged a school bus service for this group of students. Before 2016 the school hardly had any experience of teaching students with multi-ethnic backgrounds.

This study is part of an ongoing research- and development program concerning elementary schools' work with newly arrived students. The program was initiated and co-financed by a research institute, Ifous, which stands for Innovation, research and development in preschool and school, which runs a number of research- and development program that focus on different topics. The project is also financed by the participating municipality and Mälardalen University of Sweden. This project aims to develop school practice and produce practice-based research.

Methodologically the overall project presented is based on a method called research circles. The term "forskningscirklar" is well established in Sweden but there is no word in English for this particular method, so we have chosen to use 
a direct translation of the Swedish term, research circles. In short, research circles are places for practitioners and researchers to meet, exchange ideas and develop both research and practice for further information on research circles as a method, see Jepson Wigg \& Ehrlin (2018). As stated earlier, some of the problems we were told about during the research circles held at Countryside School, led us to the decision to complement the collection of data with interviews.

The interviews held were semi-structured, qualitative research interviews, which Kvale \& Brinkmann (2014) calls "conversational interviews". The interviews were conducted at the school. We performed nine interviews; three interviews together, and three each individually. We interviewed eight teachers and the principal at the school. Five of the teachers interviewed were part of the ongoing research- and development program concerning elementary schools' work with newly arrived students and were also asked to also participate in interviews and besides that three other teachers at the school were asked to participate. The participants' years of experience vary from 5 to $30+$ years. Six of the interviews lasted from 40 to 52 minutes and two of them lasted for 15 minutes depending on difficulties to find time in the schedule of these two teachers. The interviews where recorded in full, with written permission from the participants.

The conversational interviews were based on an interview guide which used open as well as leading questions to incite stories and reflections that were concentrated around a number of themes. The semi-structured approach meant that each conversational interview took a slightly different direction. The transcribed data material was analyzed using a qualitative method of analysis (Kvale \& Brinkman, 2014). During the first stage of the analysis, the content of the transcribed conversational interviews was categorized by establishing a number of themes in the interviewees' life-world perspectives. In the second stage, aspects of these perspectives were theorized using an abductive method (Alvesson \& Sköldberg, 2017). The Swedish Research Council's ethical principles (The Swedish Research Council, 2017) regarding information, consent, confidentiality and use were taken into account when conducting this research. Since this is a small school, confidentiality is of special importance. We have chosen to use only fabricated female names for the interviewees, and have chosen not to include descriptions of subjects they teach or other identifying characteristics. There is no doubt, however, who the principal of the school is, and for that reason, we have chosen to use that interview mainly as a contextualisation. In the presentation of the results we have chosen excerpts from the transcripts that capture the sense of what was being said.

\section{Empirical Findings}

The findings are presented in two sections. The first describes the principals', Doris, experiences and thoughts under the theme The organisational context and decisions. The second section presents the thematic analysis of the teachers' experiences. The themes are: A sudden change, Preparations and support, Limitations and frustration and Imprints in the practice. 
The organisational context and decisions

During the spring of 2016, the principal, Doris, was given information from the municipality that Countryside School might, as she puts it, be given a possibility to receive a group of 30 newly arrived student. Doris saw this as important:

"And I thought, this is a train we just can't miss, considering / .../ we have a very, how do you say, homogeneous group of students here. So I thought it would be good because, we can't miss this opportunity."

An explicit reason for Doris to agree to receive these students, then, was to increase diversity at the school and in the community. Since Countryside School is set in a rural community with very few immigrants, the principal saw an opportunity to introduce diversity.

After the initial question from the municipality, it wasn't until just before the summer holidays that Doris was given final information that the students would attend the school the following semester. This late decision meant that the principal couldn't inform anyone at the school, teachers or students, until after the summer.

Doris chose not to discuss the possibility of this change before everything was decided, partly because it was unclear what was going to happen, and partly because she saw the decision as an easy one:

"It was decided very late, formally very late. So I informed the teachers that "we have been given a task to perform", so there wasn't much room for dialogue around "should we or shouldn't we?" It was a non-issue."

This drawn-out process meant that Doris had to start planning for receiving the students at very short notice. The main issue at the beginning of the school year, was to recruit teachers and support staff with experience of working with newly arrived students. The school was not successful in that regard, since there was a shortage of these teachers due to the high number of refugees coming to Sweden at the time. Eventually, three people were hired that were not teachers, but had some experience in working with newly arrived students.

At the beginning of the semester, the teachers at the school were given some training and support, by staff from the municipality who receive all the newly arrived students initially. The training included a lecture in scaffolding language and learning according to a certain method.

Most of the teachers at the school were not involved in teaching the newly arrived students from the beginning, since the students were placed in an introductory group. After about half a year, Doris realised that these students had become separated from the other students at the school, and that they were not an integrated part of school life.

"And we discovered that these students were an isolated group. They want to be in [regular] classes. And then I made that decision that these students have to be in [regular] class. We have 
to have the resources in the classrooms, because these students have to be everybody's responsibility /.../ we have to do something otherwise they'll be isolated, and that leads to other things, there'll be much more "us and them".

Apart from the challenges in planning and supporting teachers and students, Doris' experience is that the new situation also led to challenges in teaching. Doris expresses some surprise that not all of the teachers at the school took to the challenges the way she had expected:

"The range of what is normal in the classroom increases. And I think you either have to think "well, how do I approach this differently? How do I plan my teaching so that it fits all of the students?" Or "I will plan my teaching to fit these students, and the rest have to cope the best they can". I think there's a large variation."

Doris had expected that the teachers would be more willing to question and change their teaching methods to benefit the newly arrived students, but some of the teachers found this difficult, she says: "... this readiness to adjust your own teaching, I thought that readiness was higher." As a result, it became difficult for the principal to plan how to best utilize resources in the classroom, and she describes the solutions and the support as a bit of a patchwork.

In Doris' experience, not all the teachers liked the change that much, but she says she chose not to give room to voice those opinions:

"I went in and said "we have this opportunity to become a diverse school". I mean if I go in with that energy, no one will say "I don't want to do this". I am aware of that. I think I minimized the space for being critical to that decision. Was that smart or not? I don't know. But I did it, because I judged that I didn't have a choice."

At the time of the interview, the newly arrived students were leaving the school. Doris thinks that despite the challenges this has been a good experience. Teachers and students having to face and deal with diversity has enriched the school and the native students at the school, she says:

"There's a great conformity here. If the students who attend the school are to have a possibility to see what it's like to live outside this place, they need to meet other people. And they got to do that for a full year. Or two. And that's a value we shouldn't disparage."

In summation, this is the principals' story and experiences of receiving the group of newly arrived students. In the next section, the experiences of eight of the teachers are in focus.

\section{A sudden change}

The teachers describe the decision to admit newly arrived students to the school as a sudden event. Some of them recall that they were informed at the beginning 
of the autumn semester that the school was about to receive 30 newly arrived students in smaller increments, starting immediately. Others do not recall precisely when or how they received the information. The teachers all describe the sudden change as perplexing, but also understandable given the circumstances in Sweden at the time. Susan expresses her experience like this:

"Suddenly, we were told that there would be newly arrived students at the school. And the way the situation was in Sweden, no one had anything to say against that. We just rolled with the punches. You can't say "no, we won't help out".

Further, the teachers aren't clear on who actually made the decision to admit the students to the school, whether it was a decision in the central administration of the municipality, or whether it was the principal. Celia says:

"There was a decision in the municipality that all schools should be prepared to receive [newly arrived students]. And I don't know if it was because the principal wanted it or because we were assigned students."

There was, then, a willingness on the part of the teachers to take on this group of students, but it was difficult to assess or anticipate what such a sudden change would bring with it and how it would affect their teaching. One aspect, which Gladys expresses, is that for most teachers, receiving that many new students into your classroom during such a short time would be a challenge:

"I mean, it never happens that you suddenly get eight new students. It's usually one or two, from time to time. Not this many at the same time, who don't speak the language. That's unique, I have to say."

Another aspect of anticipating the changes that would follow, is expressed like this by Helen:

"If I'm completely honest, I don't think I really understood the concept "newly arrived", I mean I understand what it means in general, but maybe not what it would mean for a school. And I actually don't think anyone at the school fully did."

In summation, this theme captures the teachers' sense of being taken by surprise by this organisational change. This in turn led to the teachers feeling left out of the decision-making process, and they were not given adequate time to prepare and adjust.

\section{Preparations and support}

As stated above, the teachers were surprised by the sudden change in the organisation, but they did not oppose it. However, they express that they would have needed more support and guidance in how to adjust their teaching to meet 
the needs of their new students. Carol says that there was no organised support at the beginning of the semester:

"I felt like these students were just thrown into the system, and that there was no preparedness but our principal and us colleagues were meant to solve it. Just solve it like this [snaps her fingers]. That's how I felt."

Several of the teachers say they would have needed more support and guidance from others with more experiences, for instance from other schools who receive many newly arrived students every year. They are also critical of the lack of support from the central administration of the municipality. Liza says:

"We didn't get a lot of information, well someone was here and talked about things to do, but in the end, it was like "we can't perform miracles, so do the best you can". And we didn't know where to turn for that support either. I like a challenge, I do...But this was a bit much."

Susan echoes that sentiment:

“The support function wasn't there. And one would think, our municipality, they ought to have some kind of know-how. There has to be people who develop material, come out and present it to us "here you go, period. Use this". We can't be inventing the wheel when we have so many different students. This wasn't rational."

Some of the teachers say that they were offered some support, and that they turned to each other within the work teams to find method and discuss what did and didn't work. Gladys recollects that a woman from the municipality who had worked with second language acquisition came to the school, went to lessons and observed, and gave the teachers advice. Monica emphasises the collegial support and reading books to find ideas and inspiration. Despite this, the overall interpretation is that there was a lack of support. As Susan puts it, they still had the same variation of students in their classrooms, with different needs and abilities, and then:

"... on top of that, a larger number of students with different languages. They weren't a homogenous group either, some of them had gone to school, someone knew English, and some had never gone to school. We didn't have the knowledge, and we weren't offered any help."

A possible solution, according to Gladys, would have been if the entire school had come together and worked collectively on possible ways of developing their teaching. The way it was now, Gladys means that the teachers were left to their own devices to a large extent.

In summation, this theme captures the teachers' experiences of facing a task they did not feel prepared for. It also points to a desire to develop their teaching methods and the disorientation they felt due to a lack of support in that process. 


\section{Limitations and frustration}

The teachers' experiences described in the previous themes, led to feelings of being limited as a professional. None of the teachers express that they didn't want to help or didn't want the school to receive these students. What they do express is a frustration in being underprepared and in not knowing how to amend the situation. Helen says:

"I think I trusted the people who made these decisions, like my principal, that she knew, but the more we talked about this, the more we realized that no one really knew what the students /.../ what abilities they had in Swedish /.../ I felt like this was beyond my competence in a way because this was language acquisition at a basic level, and I don't have that competence."

Asking for support and not receiving it the way they felt they needed was another source of frustration, as Amy states:

"I kept going on about needing more... I don't know enough /... / I was annoyed, but I was annoyed because I wanted support to make it work, and the solution was to remove the students [from my class] instead. But I wasn't trying to get them removed, I wanted support in how to teach them."

Helen and Susan use even stronger language when they describe their feelings as professionals in this situation. Susan expresses a sense of shame in not being able to do her job they way she wants to:

"I was ashamed during that time. I was ashamed. I felt so bad, it was so... I can't, I don't know what to do /.../ I mean, we have a charge, I feel that these students need more help, they aren't to blame for the way things are /.../ I am responsible for that in a way, I am. But I am a part of a system, and it's not very satisfying when I see that the system isn't holding up."

Helen means that this is also an issue of professional ethics, and describes a sense being conflicted regarding the scope of her responsibilities:

"You want to break free from that responsibility as an individual /.../ but it's partly my responsibility too, because I don't want it to be my problem /.../ it could be an organisational issue, that there was no support, you had to go it alone. And then when the whole group [of colleagues] came together, decisions were made that didn't benefit the students. Yeah, it's almost like an ethical standpoint "I can't do this anymore, do I save myself or..."

The conflict for Helen is between her own well-being on the one hand and continuing trying to help the students on the other.

In summation, this theme captures the teachers' frustration of being limited as professionals, and no longer being competent in handling the new situations 
that arise in their teaching. This touches on central issues in their professional practice such as planning their teaching and being able to help students learn.

\section{Imprints in the practice}

As stated earlier, at the time of the interviews, almost all the newly arrived students had left the school, and the rest were about to leave. The teachers talk about the traces this period has left at the school, and in their practice, and their thoughts on this differ somewhat. Monica expresses a belief that the students has enriched the school and changed teaching practices:

"I do think our school is richer for these experiences, I do. They won't go away. And they'll change the teaching for those who actually looked at themselves and scrutinized their practice, because you have to do that sometimes."

Gladys isn't as sure as Monica that this experience will leave permanent imprints:

"Hopefully it did. But the risk is that if there aren't any newly arrived students at all [at the school] /.../ the risk is that it will just be an exception. It might be. That you forget, the [Swedish] students that attended the school then have left, and the new students won't think about it."

Susan and Amy both express that they wouldn't want the school to receive more newly arrived students under the same circumstances. But as Susan says:

"If you build a sensible organisation, otherwise no / .../ definitely not. But if we have to, in the name of solidarity, of course we should. But you would want a better organisation."

Monica also wishes for a better organisation, but states that she wants the school to have a continuous reception of newly arrived students:

"It would be good for everything here. Because it was like an interlude, they arrived and then they disappeared. It's not good for the practice, we ought to have a certain percentage. I think it would be good for integration overall."

In summation, the teachers state that they would like to have more newly arrived students at the school, but only under the right circumstances, with a robust organisation in place and support in developing one's own teaching.

\section{Discussion}

The teachers and the principal are in agreement that the situation they found themselves in was difficult to manoeuvre. It was not the suddenness of the decision in itself, or how it was announced, that caused problems. Rather, it was the lack of preparations and support once this was decided. The principal states that she expected the teachers to see the benefits of a more diverse school and thought they would take on the challenge of teaching this new group of students and change their teaching accordingly. The teachers, on their part, felt they were 
not up to the task on their own, and wanted more support and clearer guidelines. Our interpretation is that there was an idea that potential problems could be handled, because receiving these students at the school was for a good purpose. It would make the school more diverse, the native students at this rural school would get to see more aspects of society, and the teachers would develop their teaching methods. This can be put in relation to previous research about newly diverse schools, where certain aspects were pinpointed as effective strategies in handling diversity (Simó \& Telford, 2012). One aspect concerns training for teachers, which includes time for reflection and developing structures to support teaching. Another study highlights that without proper support structures, teaching newly arrived students risks being a string of ad hoc-solutions (Devine \&McGillicuddy, 2016). An antidote to this, according to previous studies, is to adopt a holistic perspective on work with newly arrived students (Adelman \& Taylor, 2015; Pastoor, 2015; Nilsson \& Bunar, 2016; Devine \& McGillicuddy, 2016; Dryden-Peterson, 2017). Our interpretation is that in the case of Countryside School, the lack of planning and experience forced the principal and the teachers to improvise solutions, which led to, as the principal puts it, a patchwork of methods.

Understanding Countryside School as a community of practice, this ad hocapproach can be theorized as an illustration of what may happen to the participants in a practice, when the practice changes rapidly. Learning in a community of practice entails becoming a more and more competent and central participant over time. When there is a sudden change in the practice, such as in this case, the participants seem to make the opposite journey, in becoming more peripheral in the community of practice. In their classrooms, the teachers now had students who did not understand Swedish, many of them had limited school backgrounds and the teachers did not have sufficient methods or knowledge about how to teach these newly arrived students and support their learning alongside other students.

As professionals, the teachers describe no longer feeling competent in teaching, in relation to the newly arrived students. For some, this led to disorientation. Our interpretation is that this also led to the teachers perceiving one another as more or less willing to cooperate in finding methods and materials for these students.

As a legitimately peripheral participant in a community of practice, there is acceptance for participants not to know things, or not to be able to perform all tasks. As beginners, we are not expected to contribute in full. Some of the teachers at Countryside School, felt alienated and isolated in the new situation the found themselves in. Others were able to work their way back towards the centre more or less on their own, by seeking information and literature regarding for instance the method of scaffolding. Here, we want to make a theoretical point, saying that the teachers who described being able to cope did see themselves as placed in a new context or practice, and therefore acted as legitimately peripheral participants. Their colleagues who were isolated did not and because of this became stuck on the outer edge with fewer possibilities to act as competent participants in order to make the journey back to the centre. 
Another interpretation is that the community of practice at the school has a culture of trust in teachers' self-sufficiency. When the teachers are central participants in the practice, this is a good thing in that it shows respect for the teachers' autonomy and competence as actors. In order to create support for the teachers when they no longer felt competent in the new situation, the school would have to:... "make sure that participants have access to the resources necessary to learn what they need to learn in order to take actions and make decisions that fully engage their own knowledgeability" (Wenger, 2018, p.225).In this case, the culture of trust in teachers' self-sufficiency in the community of practice might have prevented necessary resources to support the teachers.

\section{Conclusions and Recommendations}

The purpose of this article was to examine and analyse teachers' and their principal's experiences of receiving a group of newly arrived students at a newly diverse school, in order to highlight how this impacts professional practice and what is important to take into account when receiving and teaching newly arrived students. The principal and some of the teachers meant that having the newly arrived students attend the school would contribute diversity and perspective to the other students and to the community. As well intended as that aim was the lack of preparations and support for the teachers, caused problems since the sudden change was not merely a change in student demographics but a significant change in the community or practice. Based on the result of the study our recommendations are that such a change would have needed more focus on preparations and structures for reflection and support, so that the teachers would be able to develop their teaching in relation to the newly arrived students.

This article contributes to educational research regarding what is necessary for newly diverse schools to take into account when receiving newly arrived students. We cannot draw any conclusions regarding how Countryside School actually fared, or how the newly arrived students who attended the school experienced their schooling. The image presented by the teachers seems to indicate that they failed in teaching these students. It is possible; however, that the teachers did succeed in their teaching, but what is important here is the experiences they express of not having been able to teach in a way they can take professional pride in. According to Wenger (1998) when there is a lack of communication in a community of practice, this creates gaps in potential for participants to be competent actors. This seems especially crucial to keep in mind in a complex practice like teaching newly arrived students.

\section{References}

Adelman, H., \& Taylor, L. (2015). Immigrant children and youth in the USA: Facilitating equity of opportunity at school. Education Sciences, 5(4), 323-344. https:// doi.org/10.3390/educsci5040323

Alvesson, M. \& Skölberg, K. (2017). Tolkning och reflektion. Vetenskapsfilosofi och kvalitativ metod. [Interpretation and Reflection: Philosophy of Science and Qualitative Method]. Lund: Studentlitteratur. 
Bartlett, L. (2015). Access and quality of education for international migrant children. Background paper prepared for the Education for All Global Monitoring Report, 2000-2015.

Bunar, N. (2015). Elevsammansättning, klyftor och likvärdighet i skolan. [Student grouping, gaps and equality in school]. Policy report, City of Stockholm.

Catarci, M. (2014). Intercultural education in the European context: Key remarks from a comparative study. Intercultural Education, 25(2), 95-104. https://doi.org/10.1080/14675986.2014.886820

Devine, D., \& McGillicuddy, D. (2016). Positioning pedagogy - A matter of children's rights. Oxford Review of Education, 42(4), 424-443. https://doi.org/10.1163/15718182-02604003

Dryden-Peterson, S. (2017). Refugee education: Education for an unknowable future. Curriculum Inquiry, 47(1), 14-24. https:// doi.org/10.1080/03626784.2016.1255935

Dryden-Peterson, S. (2016). Refugee education: The crossroads of globalization.Educational Researcher, 45(9), 473-482. https://doi.org/10.3102/0013189X16683398

Hattam, R., \& Every, D. (2010). Teaching in fractured classrooms: Refugee education, public culture, community and ethics. Race Ethnicity and Education, 13(4), 409424. https:// doi.org/10.1080/13613324.2010.488918

Jepson Wigg, U. \& Ehrlin, A. (2018). Systematic Quality Development: A demand at odds with the everyday complexity of teachers' work? International Journal of learning, teaching and educational research, 17(11), 194-206. https:// doi.org/10.26803/ijlter.17.11.12

Jepson Wigg, U. (2016). Betydelsefulla skeden - från introducerande till ordinarie undervisning. In $\mathrm{P}$, Lahdenperä \& E, Sundgren (eds.). Skolans möte med nyanlända. [The school's meeting with newly arrived students]. Stockholm: Liber.

Kvale, S. \& Brinkmann, S. (2014). InterViews. Learning the Craft of Qualitative Research Interviewing. London: Sage.

Migliarini, V. (2017). Subjectivation, agency and the schooling of raced and dis/abled asylum-seeking children in the Italian context. InterculturalEducation, 28(2), 182195.

https:/ / doi.org/10.1080/14675986.2017.1297091

Nilsson, J. \& Bunar, N. (2016). Educational responses to newly arrived students in Sweden: Understanding the structure and influence of post-migration ecology. Scandinavian Journal of Educational Research,60(4), 399-416. https:/ / doi.org/10.1080/00313831.2015.1024160

OECD Reviews of Migrant Education. (2018). (2019-06-20). The Resilience of Students with an Immigrant Background: Factors that shape well-being. OECD Publishing, Paris. Retrieved: http://dx.doi.org/10.1787/9789264292093-en

Pastoor, L.d.W. (2015). The mediational role of schools in supporting psychosocial transitions among unaccompanied young refugees upon resettlement in Norway. International Journal of Educational Development, 41, 245-254. https://doi.org/10.1016/j.ijedudev.2014.10.009

RAND Europe (2016). (2019-06-20). Education of Migrant Children. Education Policy Responses for the Inclusion of Migrant Children in Europe. RAND Corporation \& the European Union. Retrieved: https://www.rand.org/pubs/research_reports/RR1655.html 
Simó, N., \& Telford, J. (2012). Vic: The challenges facing schools in a small, newly diverse, Catalan city. Improving Schools, 15(3), 211-227. https://doi.org/10.1177/1365480212461089

SFS2010:800. (209-06-20). Skollag. [The Education Act]. Stockholm: Department of Justice. Retrieved: https://www.riksdagen.se/sv/dokument-lagar/dokument/svenskforfattningssamling/skollag-2010800_sfs-2010-800

Swedish Research Council. (2019-06-20). Forskningsöversikt 2019, Utbildningsvetenskap.[Overview of Educational Research]. Retrieved:https://www.vr.se/analys-och-uppdrag/vi-analyserar-ochutvarderar/alla-publikationer/publikationer/2019-01-29-forskningsoversikt2019--utbildningsvetenskap.html

Swedish Research Council (2017). God forskningssed. [Good Research Practice]. Stockholm: Swedish Research Council.

Wenger, E. (2018). A Social Theory of Learning. In K. Illeris (ed.). Contemporary Theories of Learning. Learning Theorists in Their Own Words. (2 ed., p. 219-228). New York:Routledge. https://doi.org/10.4324/9781315147277

Wenger, E. (1998). Communities of Practice. Learning, meaning and identity. Cambridge: Cambridge University Press. 